\title{
Cytotoxic Lathyrane Diterpenoids from the Roots of Euphorbia
}

\author{
fischeriana
Jue Li $\oplus^{1}$, Jianlin $\mathrm{He} \oplus^{1}$, Chunai Yang $\oplus^{1}$, Xuelong Yan $\oplus^{2 *}$ and Zhao Yin ${ }^{1^{*}}$ \\ ${ }^{I}$ The Second People's Hospital of Yunnan Province, Kunming 650021, P. R. China \\ ${ }^{2}$ School of Pharmaceutical Sciences, Sun Yat-sen University, Guangzhou, 510006, P. R. China
}

(Received December 08, 2019; Revised February 03, 2020; Accepted February 11, 2020)

\begin{abstract}
Two new lathyrane diterpenoids, euphofischers A and B (1 and 2), along with three known analogues (3-5), were isolated from the roots of Euphorbia fischeriana. Their structures were elucidated by spectroscopic analysis. Euphofischer A (1) represents rare example of a lathyrane diterpenoid featuring a 15-p-coumaroyl moiety. All compounds were screened for their cytotoxicity against three cancer cell lines $(\mathrm{C} 4-2 \mathrm{~B}, \mathrm{C} 42 \mathrm{~B} / \mathrm{ENZR}$, and MDA-MB-231), and compound $\mathbf{1}$ exhibited significant cytotoxicity against C4-2B cell line, with an $\mathrm{IC}_{50}$ value of $11.3 \mu \mathrm{M}$.
\end{abstract}

Keywords: Euphorbia fischeriana; Euphorbiaceae; lathyrane; diterpenoid. (C) 2020 ACG Publications. All rights reserved.

\section{Plant Source}

In the current phytochemical investigation regarding traditional Chinese medicine (TCM), two new lathyrane diterpenoids and three known analogues were isolated from the roots of Euphorbia fischeriana Steud. (Euphorbiaceae) (Plant materials see supporting information). We report herein the isolation, structure elucidation, and cytotoxicities of these compounds (Figure 1).

\section{Previous Studies}

Euphorbia fischeriana, a perennial herb widely distributed in northern provinces of China, is known as "Lang Du" in traditional Chinese medicine (TCM) for its treatment of tuberculosis, edema, and cancer [1,2]. Previous phytochemical studies on this plant have demonstrated that lathyrane, tigliane, ent-atisane, ent-abietane diterpenoids and diverse terpenoids are the main constituents of $E$. fischeriana, and some of them possessed significant biological properties, such as antituberculosis, cytotoxic, antiinflammatory and anti-HIV activities [3-8].

*Corresponding authors: E-Mail: 469105780@qq.com (X-L. Yan), 25456109@qq.com (Z. Yin). 


\section{Present Study}

The EtOAc extract of the roots of E. fischeriana was separated with a series of column chromatographic method to afford compounds 1-5 (detailed separation process see supporting information). Their structures were identified as shown in Figure 1.

Euphofischer A (1): $[\alpha]^{20}{ }_{\mathrm{D}}-188.2\left(c 0.30, \mathrm{CHCl}_{3}\right) ; \mathrm{UV}(\mathrm{MeOH}) \lambda_{\max }(\log \varepsilon) 273(4.04) \mathrm{nm}$; IR $(\mathrm{KBr})$ $v_{\max } 3391,2930,1703,1603$, and $1153 \mathrm{~cm}^{-1} ;{ }^{1} \mathrm{H}$ and ${ }^{13} \mathrm{C}$ NMR data see Table 1 ; HRESIMS $\mathrm{m} / \mathrm{z}$ $481.2589[\mathrm{M}+\mathrm{H}]^{+}$(calcd. for $\mathrm{C}_{29} \mathrm{H}_{37} \mathrm{O}_{6}{ }^{+}, 481.2585$ ) and $479.2430[\mathrm{M}-\mathrm{H}]^{-}$(calcd. for $\mathrm{C}_{29} \mathrm{H}_{35} \mathrm{O}_{6}{ }^{-}$, 479.2439).

Euphofischer B (2): $[\alpha]^{20}{ }_{\mathrm{D}}-70.7\left(c 0.90, \mathrm{CHCl}_{3}\right)$; UV (MeOH) $\lambda_{\max }(\log \varepsilon) 277$ (4.40) nm; IR (KBr) $v_{\max } 3481,2933,1717,1633,1235$, and $1153 \mathrm{~cm}^{-1} ;{ }^{1} \mathrm{H}$ and ${ }^{13} \mathrm{C}$ NMR data see Table 1; HRESIMS m/z $545.2517[\mathrm{M}+\mathrm{Na}]^{+}$(calcd. for $\mathrm{C}_{31} \mathrm{H}_{38} \mathrm{O}_{7} \mathrm{Na}^{+}, 545.2510$ ).
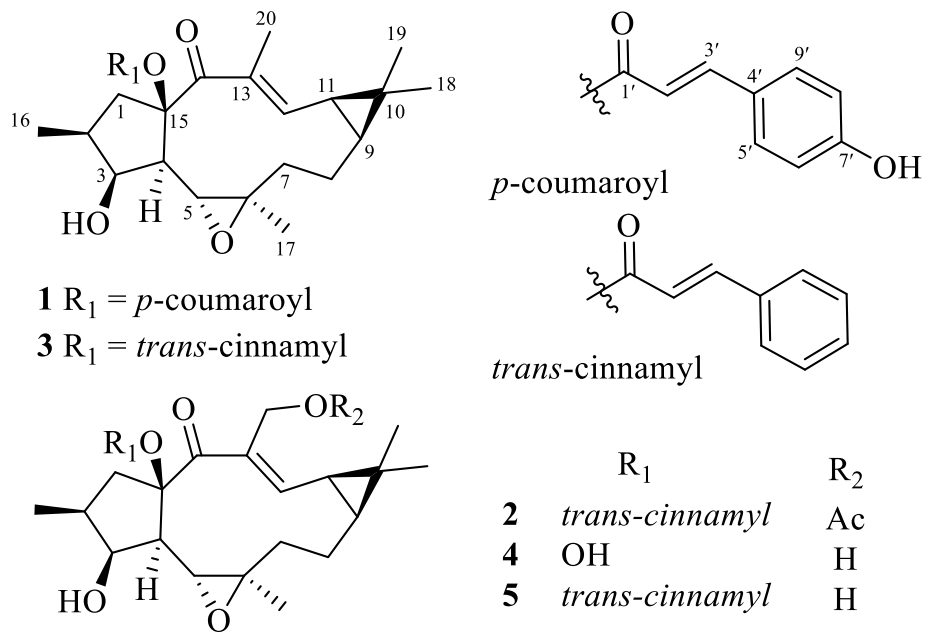

Figure 1. Structures of compounds 1-5

Compound 1 was isolated as a white powder. The pseudomolecular-ion peaks in the HRESIMS at $m / z 481.2589$ for $[\mathrm{M}+\mathrm{H}]^{+}$(calcd. for $\mathrm{C}_{29} \mathrm{H}_{37} \mathrm{O}_{6}{ }^{+} 481.2585$ ) and at $m / z 479.2430$ for $[\mathrm{M}-\mathrm{H}]^{-}$ (calcd. for $\mathrm{C}_{29} \mathrm{H}_{35} \mathrm{O}_{6}{ }^{-} 479.2439$ ) allowed the molecular formula $\mathrm{C}_{29} \mathrm{H}_{36} \mathrm{O}_{6}$ to be assigned to 1 . The IR spectrum absorption bands at $3391 \mathrm{~cm}^{-1}$ and $1703 \mathrm{~cm}^{-1}$ suggested the presences of hydroxyl and carbonyl groups, respectively. The ${ }^{1} \mathrm{H}$ NMR data (Table 1) showed the signals for five methyl groups $\left(\delta_{\mathrm{H}} 0.81,1.09,1.10,1.18\right.$, and 1.86$)$, three olefinic protons $\left(\delta_{\mathrm{H}} 6.21,6.97\right.$, and 7.56$)$, two oxymethine protons $\left(\delta_{\mathrm{H}} 3.67\right.$ and 4.15$)$, a disubstituted phenyl ( $\delta_{\mathrm{H}} 6.82$ and 7.30 ), and a series of aliphatic multiplets. The ${ }^{13} \mathrm{C}$ NMR spectrum, associated with the DEPT and HSQC experiments (Table 1), classified 29 carbon resonances for a conjugated ketocarbonyl $\left(\delta_{\mathrm{C}} 195.2\right)$, a $p$-coumaroyl group $\left(\delta_{\mathrm{C}}\right.$ $114.5,115.9 \times 2,126.5,130.1 \times 2,146.2,158.5$, and 166.0), a trisubstitued double bond $\left(\delta_{\mathrm{C}} 134.0\right.$ and 144.4), two oxygenated $\mathrm{sp}^{3}$ tertiary carbons ( $\delta_{\mathrm{C}} 64.5$ and 91.7$)$, five methyls, three $\mathrm{sp}^{3}$ methylenes, six $\mathrm{sp}^{3}$ methines (two oxymethines at $\delta_{\mathrm{C}} 58.5$ and 78.8), and a quaternary carbon. The above-mentioned NMR data exhibited a high similarity to that of a co-isolated known compound jolkinol B (3) [9] (Table S1), except for the replacement of a trans-cinnamyl group in $\mathbf{3}$ by a $p$-coumaroyl group in $\mathbf{1}$. This was supported by comparison of the ${ }^{1} \mathrm{H}$ and ${ }^{13} \mathrm{C}$ NMR data of $p$-coumaroyl moiety in 1 with those of $p$-coumaric acid [10], as well as the HMBC correlations from $\mathrm{H}-5^{\prime} / \mathrm{H}-9^{\prime}$ and $\mathrm{H}-6^{\prime} / \mathrm{H}-8^{\prime}$ to an aromatic oxygenated quaternary carbon $\left(\delta_{\mathrm{C}} 158.5, \mathrm{C}-7^{\prime}\right)$. Detailed analysis of $2 \mathrm{D}$ NMR data, especially the ${ }^{1} \mathrm{H}-{ }^{1} \mathrm{H}$ COSY and HMBC correlations, supported the assignment of the planar structure of $\mathbf{1}$ as shown in Figure 1. 
Table 1. ${ }^{1} \mathrm{H}$ NMR (400 MHz) and ${ }^{13} \mathrm{C}$ NMR $(100 \mathrm{MHz})$ data for 1 and 2 ( $\delta$ in ppm)

\begin{tabular}{|c|c|c|c|c|}
\hline \multirow[b]{2}{*}{ No. } & \multicolumn{2}{|l|}{1} & \multicolumn{2}{|l|}{2} \\
\hline & $\delta_{\mathrm{H}}$, mult. $(\mathrm{J}$ in Hz) & $\delta_{\mathrm{C}}$ & $\delta_{\mathrm{H}}$, mult. $(J$ in $\mathrm{Hz})$ & $\delta_{\mathrm{C}}$ \\
\hline $1 \alpha$ & $3.53, \mathrm{dd}(13.3,7.6)$ & 45.0 & $3.53, \mathrm{dd}(13.4,7.4)$ & 44.3 \\
\hline $1 \beta$ & $1.73, \mathrm{dd}(13.3,13.3)$ & & $1.75, \mathrm{dd}(13.4,13.4)$ & \\
\hline 2 & $2.02, \mathrm{~m}$ & 38.5 & $2.02, \mathrm{~m}$ & 38.4 \\
\hline 3 & $4.15, \mathrm{dd}(3.7,3.7)$ & 78.8 & $4.14, \mathrm{dd}(3.6,3.6)$ & 78.5 \\
\hline 4 & $1.57, \mathrm{dd}(9.4,3.7)$ & 52.1 & $1.63, \mathrm{~m}$ & 51.6 \\
\hline 5 & $3.67, \mathrm{~d}(9.4)$ & 58.5 & $3.64, \mathrm{~d}(9.3)$ & 58.1 \\
\hline 6 & & 64.5 & & 63.6 \\
\hline $7 \mathrm{a}$ & $1.62, \mathrm{~m}$ & 38.6 & $1.63, \mathrm{~m}$ & 38.5 \\
\hline $7 b$ & $2.05, \mathrm{~m}$ & & $2.05, \mathrm{~m}$ & \\
\hline $8 \alpha$ & $2.01, \mathrm{~m}$ & 23.2 & $2.10, \mathrm{~m}$ & 23.3 \\
\hline $8 \beta$ & $1.51, \mathrm{~m}$ & & $1.56, \mathrm{~m}$ & \\
\hline 9 & $1.12, \mathrm{~m}$ & 33.8 & $1.27, \mathrm{~m}$ & 35.2 \\
\hline 10 & & 26.3 & & 28.0 \\
\hline 11 & $1.47, \mathrm{dd}(11.0,7.8)$ & 29.7 & $1.67, \mathrm{dd}(10.8,7.8)$ & 29.8 \\
\hline 12 & $6.97, \mathrm{~d}(11.0)$ & 144.4 & $7.27, \mathrm{~d}(10.8)$ & 150.7 \\
\hline 13 & & 134.0 & & 132.4 \\
\hline 14 & & 195.2 & & 193.1 \\
\hline 15 & & 91.7 & & 91.8 \\
\hline 16 & $1.10, \mathrm{~d}(6.9)$ & 13.2 & $1.10, \mathrm{~d}(6.7)$ & 13.1 \\
\hline 17 & $1.18, \mathrm{~s}$ & 20.0 & $1.24, \mathrm{~s}$ & 20.0 \\
\hline 18 & $1.09, \mathrm{~s}$ & 29.0 & $1.12, \mathrm{~s}$ & 29.0 \\
\hline 19 & $0.81, \mathrm{~s}$ & 16.1 & $0.87, \mathrm{~s}$ & 16.2 \\
\hline 20 & $1.86, \mathrm{~s}$ & 12.4 & $\begin{array}{l}\text { a } 4.92, \mathrm{~d}(11.5) \\
\text { b } 4.98, \mathrm{~d}(11.5)\end{array}$ & 58.1 \\
\hline $1^{\prime}$ & & 166.0 & & 165.4 \\
\hline $2^{\prime}$ & $6.21, \mathrm{~d}(15.8)$ & 114.5 & $6.44, d(16.0)$ & 117.1 \\
\hline $3^{\prime}$ & 7.56, d (15.8) & 146.2 & $7.69, \mathrm{~d}(16.0)$ & 146.8 \\
\hline $4^{\prime}$ & & 126.5 & & 133.8 \\
\hline $5^{\prime} / 9^{\prime}$ & $7.30, d(8.5)$ & 130.1 & $7.47, \mathrm{~d}(7.5)$ & 128.2 \\
\hline $6^{\prime} / 8^{\prime}$ & $6.82, \mathrm{~d}(8.5)$ & 115.9 & $7.40, \mathrm{~m}$ & 129.0 \\
\hline $7^{\prime}$ & & 158.5 & $7.40, \mathrm{~m}$ & 130.8 \\
\hline$-\mathrm{OOCCH}_{3}$ & & & & 170.9 \\
\hline$-\mathrm{OOC} \underline{\mathrm{C}} \mathrm{H}_{3}$ & & & $1.98, \mathrm{~s}$ & 20.9 \\
\hline
\end{tabular}
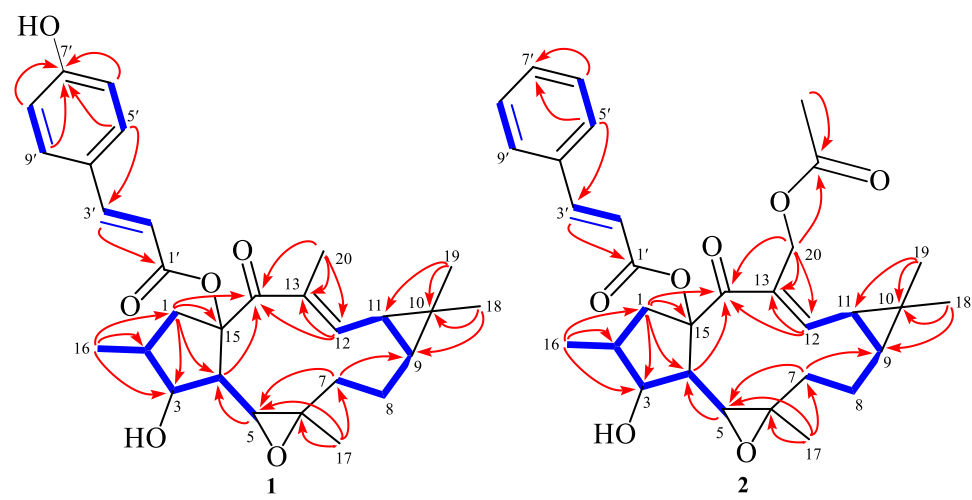

Figure 2. ${ }^{1} \mathrm{H}-{ }^{1} \mathrm{H} \operatorname{COSY}(-)$ and key $\operatorname{HMBC}(\longrightarrow)$ correlations of $\mathbf{1}$ and 2 
Interpretations of the NOE correlations and ${ }^{1} \mathrm{H}-{ }^{1} \mathrm{H}$ coupling constants (Figure 3) allowed the assignments of the relative configuration of compound 1. Firstly, the strong NOE correlations of $\mathrm{H}$ $4 / \mathrm{H}_{3}-17$ and $\mathrm{H}-5 / \mathrm{H}-8 \beta$ indicated that $\mathrm{H}-5$ was in a trans-positon of $\mathrm{CH}_{3}-17$ on the epoxy ring, which was further confirmed by comparison of the NMR data of C-5 and C-6 in 1 with those of known analogue jolkinol B (3) (Table S1). Thus, $\mathrm{H}-4$ and $\mathrm{CH}_{3}-17$ were arbitrarily designated as $\alpha$ orientations, while $\mathrm{H}-5$ was $\beta$-oriented. Subsequently, the NOE correlations from $\mathrm{H}-3$ to $\mathrm{H}-2$ and $\mathrm{H}-4$ and from $\mathrm{H}-2$ to $\mathrm{H}-4$, together with small coupling constant of $\mathrm{H}-3(\mathrm{dd}, J=3.7,3.7 \mathrm{~Hz}$ ) indicated that $\mathrm{H}-2$ and H-3 were $\alpha$-oriented [11]. A cis-orientation for the $\beta$-oriented dimethylcyclopropane moiety was established by the NOE correlations of $\mathrm{H}-9 / \mathrm{H}-11$ and $\mathrm{H}-8 / \mathrm{CH}_{3}-19$. The NOE correlation of $\mathrm{H}-$ $11 / \mathrm{CH}_{3}-20$ determined the $E$-geometry for $\Delta^{12(13)}$ double bond. The trans-relationship of H-4 and 15-pcoumaroyl was proposed to be the same as that $\mathbf{3}$ and other analogues based on biosynthetic considerations and its ${ }^{13} \mathrm{C}$ chemical shifts at C-15 $\left(\delta_{\mathrm{C}} 91.7\right)$ and C-4 $\left(\delta_{\mathrm{C}} 52.1\right)[9,11-13]$. Thus, the structure of $\mathbf{1}$ was determined and was given a trivial name euphofischer $\mathrm{A}$.

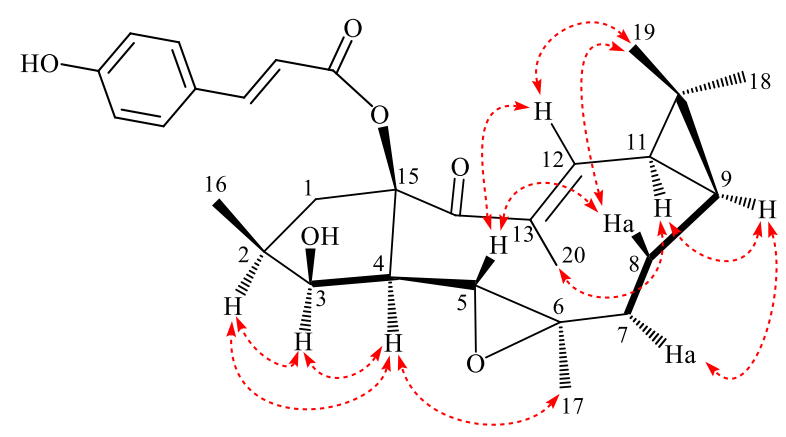

Figure 3. key NOE $(\leftrightarrow \cdots \cdots)$ ) correlations of 1

Compound 2 showed a molecular formula $\mathrm{C}_{31} \mathrm{H}_{38} \mathrm{O}_{7}$ as determined by its HRESIMS data. Its 1D NMR data resembled that of jolkinol A (5) [14] (Table S1), with the major difference being the presence of an additional acetyl group $\left(\delta_{\mathrm{H}} 1.98 ; \delta_{\mathrm{C}} 170.9\right.$ and 20.9$)$ in 2 , indicating that 2 was an acetylated derivative of $\mathbf{5}$. HMBC correlations from $\mathrm{H}_{\mathrm{a}}-20$ and $\mathrm{H}_{\mathrm{b}}-20$ to the additional carbonyl carbon assigned that the acetyl group was located at $\mathrm{OH}-20$. This was further supported by the severely downfield-shifted $\mathrm{H}_{2}-20$ signals in $\mathbf{2}$ with respect to that in $\mathbf{5}$ ( $\delta_{\mathrm{H}} 4.92$ and 4.98 in $\mathbf{2} ; \delta_{\mathrm{H}} 4.30$ and 4.49 in 5). The relative configuration of $\mathbf{2}$ was assigned to be the same as that of $\mathbf{5}$ based on their similar 1D NMR data and NOESY correlations. Compound $\mathbf{2}$ was named euphofischer B.

The known compounds jolkinol B (3) [9], ebracteolata C (4) [15], and jolkinol A (5) [14], were identified by comparison of their NMR data with those in the literature.

All the isolates were investigated the cytotoxicity against three cancer cells [C4-2B (human prostate cancer cells) and C4-2B/ENZR (enzalutamide-resistant C4-2B cell line), and MDA-MB-231 (human breast cancer cells)] by using the reported method [5,16]. As a result, most of these compounds showed moderate activities against $\mathrm{C} 4-2 \mathrm{~B}$ and $\mathrm{C} 4-2 \mathrm{~B} / \mathrm{ENZR}$ cell lines with $\mathrm{IC}_{50}$ values ranging from 20.9 to $37.3 \mu \mathrm{M}$, but showed weak activities against MDA-MB-231 cell line $\left(\mathrm{IC}_{50}>50\right.$ $\mu \mathrm{M})$. Particularly, compound $\mathbf{1}$ exhibited significant cytotoxicity against $\mathrm{C} 4-2 \mathrm{~B}$ cell line with an $\mathrm{IC}_{50}$ value of $11.3 \mu \mathrm{M}$ (Table 2).

Table 2. Cytotoxicities of $\mathbf{1}-\mathbf{5}$ against three cancer cell lines.

\begin{tabular}{|c|c|c|c|c|c|c|}
\hline \multirow{2}{*}{ Cell lines } & \multicolumn{6}{|c|}{$\mathrm{IC}_{50}(\mu \mathrm{M})$} \\
\hline & 1 & 2 & 3 & 4 & 5 & $\mathrm{DOX}^{\mathrm{a}}$ \\
\hline C4-2B & $11.3 \pm 0.66$ & $21.3 \pm 2.66$ & $34.3 \pm 1.34$ & $25.3 \pm 0.86$ & $20.9 \pm 0.62$ & $0.23 \pm 0.33$ \\
\hline C4-2B/ENZR & $23.2 \pm 1.22$ & $26.8 \pm 2.88$ & $37.3 \pm 3.66$ & $35.1 \pm 2.84$ & $21.9 \pm 1.96$ & $0.76 \pm 0.23$ \\
\hline MDA-MB-231 & $>50$ & $>50$ & $>50$ & $>50$ & $>50$ & $0.92 \pm 0.34$ \\
\hline
\end{tabular}


${ }^{a}$ Positive control:doxorubicin.

\section{Acknowledgments}

We cordially thank Dr. You-Kai Xu at Xishuangbanna Tropical Botanical Garden, Chinese Academy of Sciences, for his help with the plant identification.

\section{Supporting Information}

Supporting Information accompanies this paper on http://www.acgpubs.org/journal/recordsof-natural-products

\section{ORCID}

Jue Li: 0000-0002-6180-6783

Jianlin He: 0000-0003-2952-4935

Chunai Yang: 0000-0003-2749-244X

Xuelong Yan: 0000-0002-7878-7240

Zhao Yin: 0000-0001-7469-9190

\section{References}

[1] Editor Committee for Flora of China of Chinese Academy of Science (1979). Science Publishing House, Beijing. PP. 71.

[2] Chinese pharmacopoeia commission (2015). Pharmacopoeia of the People's Republic of China China Medical Science Press, Beijing. PP. 286-288.

[3] C. J. Wang, Q. L. Yan, Y. F. Ma, C. P. Sun, C. M. Chen, X. G. Tian, X. Y. Han, C. Wang, S. Deng and X. C. Ma (2017). Ent-abietane and tigliane diterpenoids from the roots of Euphorbia fischeriana and their inhibitory effects against Mycobacterium smegmatis, J. Nat. Prod. 80, 1248-1254.

[4] Y. B. Wang, R. Huang, H. B. Wang, H. Z. Jin, L. G. Lou and W. G. Qin (2006). Diterpenoids from the roots of Euphorbia fischeriana, J. Nat. Prod. 69, 967-970.

[5] X. L. Yan, J. S. Zhang, J. L. Huang, Y. Zhang, Q. J. Chen, G. H. Tang and S. Yin (2019). Euphonoids A-G, cytotoxic diterpenoids from Euphorbia fischeriana, Phytochemistry 166, 112064.

[6] Z. B. Cheng, W. Xu, Y. Y. Wang, S. Y. Bai, L. J. Liu, Z. H. Luo, W. J. Yuan and Q. Li (2019). Two new meroterpenoids and two new monoterpenoids from the deep seaderived fungus Penicillium sp. YPGA11, Fitoterapia 133, 120-124.

[7] J. W. Lee, C. Lee, Q. Jin, H. Jang, D. Lee, H. J. Lee, J. W. Shin, S. B. Han, J. T. Hong, Y. Kim, M. K. Lee and B. Y. Hwang (2016). Diterpenoids from the roots of Euphorbia fischeriana with inhibitory effects on nitric oxide production, J. Nat. Prod. 79, 126-131.

[8] L. L. Pan, P. L. Fang, X. J. Zhang, W. Ni, L. Li, L. M. Yang, C. X. Chen, Y. T. Zheng, C. T. Li, X. J. Hao and H. Y. Liu (2011). Tigliane-type diterpenoid glycosides from Euphorbia fischeriana, J. Nat. Prod. 74, 1508-1512.

[9] D. Duarte, A. Varga, G. Cherepnev, R. Radics, J. Molna, and M. J. Ferreira (2007). Apoptosis induction and modulation of P-glycoprotein mediated multidrug resistance by new macrocyclic lathyrane-type diterpenoids, Bioorg. Med. Chem. 15, 546-554.

[10] M. L. Salum, C. J. Robles and R. E. Balsells (2010). Photoisomerization of ionic liquid ammonium cinnamates: one-pot synthesis-isolation of Z-cinnamic acids, Org. Lett. 12, 4808-4811.

[11] Y. Tian, W .D. Xu, C. G. Zhu, S. Liu, Y. R. Li, L. Xiong, S. J. Wang, L. Wang, Y. C. Yang, Y. Guo, H. Sun, X. L. Wang and J. G. Shi (2011). Lathyrane diterpenoids from the roots of Euphorbia micractina and their biological activities, J. Nat. Prod. 74, 1221-1229.

[12] W. Jiao, W. W. Dong, Z. F. Li, M. C. Deng and R. H. Lu (2009). Lathyrane diterpenes from Euphorbia lathyris as modulators of multidrug resistance and their crystal structures, Bioorg. Med. Chem. 17, 47864792.

[13] C. Y. Zhang, Y. L. Wu, P. Zhang, Z. Z. Chen, H. Li and L. X. Chen (2019). Anti-inflammatory lathyrane diterpenoids from Euphorbia lathyris, J. Nat. Prod. 82, 756-764. 
[14] C. Valente, M. Pedro, J. R. Ascenso, P. M. Abreu, M. S. J. Nascimento and M. J. U. Ferreira (2004). Euphopubescenol and euphopubescene, two new jatrophane polyesters, and lathyrane-type diterpenes from Euphorbia pubescens, Planta Med. 70, 244-249.

[15] W. J. Yuan, G. P. Yang, J. H. Zhang, Y. Zhang, D. Z. Chen, S. L. Li, Y. T. Di and X. J. Hao (2016). Three new diterpenes with cytotoxic activity from the roots of Euphorbia ebracteolata Hayata, Phytochemistry Lett. 18, 176-179.

[16] Z. B. Cheng, Y. L. Li, W. Xu, W. Liu, L. J. Liu, D. G. Zhu, Y. Kang, Z. H. Luo and Q. Li (2019). Three new cyclopiane-type diterpenes from a deep-sea derived fungusPenicillium sp. YPGA11 and their effects against human esophagealcarcinoma cells, Bioorg. Chem. 91, 103129.

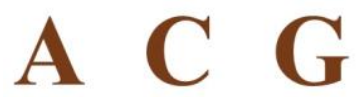

publications

(C) 2020 ACG Publications 